\title{
The implications of serum enzymes and coagulation activities in postinfarction myocardial rupture
}

\author{
As implicações de enzimas séricas e atividades de coagulação em ruptura cardíaca pós-infarto do \\ miocárdio
}

Shi-Min YUAN ${ }^{1}$, Hua JING ${ }^{2}$, Jacob LAVEE ${ }^{3}$

RBCCV 44205-1239

\begin{abstract}
Resumo
Objetivo: As associações entre doenças cardiovasculares e enzimas sorológicas ou atividades de coagulação foram amplamente documentadas em pacientes com infarto do miocárdio. No entanto, as alterações destes biomarcadores em pacientes com ruptura cardíaca após infarto do miocárdio foram raramente relatadas. $O$ objetivo deste estudo é apresentar o perfil dos biomarcadores em pacientes com ruptura cardíaca após infarto do miocárdio.
\end{abstract}

Métodos: De 2004 a 2008, 19 pacientes consecutivos foram referidos a este hospital para correção cirúrgica de ruptura cardíaca após infarto do miocárdio. Oito $(42,1 \%)$ pacientes tiveram ruptura livre de parede, cinco $(26,3 \%)$ ruptura de músculo papilar, cinco $(26,3 \%)$ ruptura do septo interventricular e um $(5,3 \%)$ ruptura dupla de estruturas, envolvendo tanto septo ventricular como parede livre. Treze pacientes sobreviveram à operação e seis faleceram. Amostras sanguíneas foram coletadas e analisadas para mensuração de enzimas sorológicas e atividade de coagulação.

Resultados: Os marcadores de coagulação e enzimas com exceção de fibrinogênio aumentaram significativamente depois do desenvolvimento da ruptura do miocárdio. Diferenças estatísticas foram achadas entre nãosobreviventes e sobreviventes em relação a concentração de dímeros-D, tempo de trombina, pico de lactato desidrogenase, creatinoquinase máximo e fração MB da creatinoquinase. Os valores de troponina I foram elevados significativamente durante os primeiros dias depois do infarto ou do reparo

1. MD, PhD; Postdoctoral Researcher, Department of Cardiothoracic Surgery, Jinling Hospital, School of Clinical Medicine, Nanjing University, Nanjing 210002, Jiangsu Province, People's Republic of China.

2. MD; Professor \& Head, Department of Cardiothoracic Surgery, Jinling Hospital, School of Clinical Medicine, Nanjing University, Nanjing 210002, Jiangsu Province, People's Republic of China.

3. MD, Associate Professor of Surgery; Deputy Director, Department of Cardiac and Thoracic Surgery, The Chaim Sheba Medical Center, Tel Hashomer 52621, Israel. cirúrgico da ruptura do miocárdio. A análise de regressão multivariada não mostrou qualquer relação significativa entre fração MB da creatinoquinase e dímeros-D nem fibrinogênio.

Conclusões: A ruptura do miocárdio induz importante elevação de marcadores enzimáticos e de atividade de coagulação, exceto fibrinogênio. As diferenças nestes biomarcadores entre não-sobreviventes e sobreviventes podem ser de grande ajuda no diagnóstico e nas decisões de tratamento, assim como na avaliação do prognóstico clínico de tais pacientes.

Descritores: Fatores de Coagulação Sanguínea. Procedimentos Cirúrgicos Cardíacos. Enzimas. Ruptura Cardíaca Pós-Infarto. Infarto do Miocárdio.

\begin{abstract}
Objectives: Associations between cardiovascular diseases and serum enzymes or coagulation activities have been sufficiently documented in patients with myocardial infarction. However, the alterations of these biomarkers in patients with postinfarction myocardial rupture have rarely been reported. The aim of this study is to present the profiles of the markers in patients with postinfarction myocardial
\end{abstract} rupture.

Methods: From 2004 to 2008, 19 consecutive patients were referred to this hospital for surgical repair of postinfarction myocardial rupture. Eight $(\mathbf{4 2 . 1 \%})$ patients had free wall

Jiangsu Province, People's Republic of China and Department of Cardiac and Thoracic Surgery, The Chaim Sheba Medical Center, Tel Hashomer 52621, Israel.

Endereço para correspondência

Shi-Min Yuan, Department of Cardiothoracic Surgery, Jinling Hospital, School of Clinical Medicine, Nanjing University, Nanjing 210002, Jiangsu Province, People's Republic of China.

E-mail: shi_min_yuan@yahoo.com 
rupture, $5(26.3 \%)$ had papillary muscle rupture, 5 (26.3\%) had ventricular septal rupture, and $1(5.3 \%)$ had double structure (ventricular septum + free wall) rupture. Thirteen patients survived the operation, and 6 died. Laboratory findings including serum enzymes and coagulation activities were collected and analyzed.

Results: The coagulation markers and serum enzymes except for fibrinogen increased significantly after the development of myocardial rupture. Statistical differences in D-dimer, partial thromboplastin time, peak lactate dehydrogenase, peak creatine kinase and creatine kinase fraction MB were found between non-survivors and survivors. Troponin I values were elevated significantly during the early days after the onset or surgical repair of myocardial

\section{INTRODUCTION}

In the event of myocardial damage secondary to acute myocardial ischemia, intracellular cardiac proteins and enzymes are released into the circulation via cardiac cell membranes [1,2]. Patients with postinfarction myocardial rupture, a severe complication of acute myocardial infarction, often develop rapid hemodynamic deterioration [3], and are usually associated with more extensive myocardial damage [4], the assessment of which has not been fully conducted in a way similar to that of the myocardial infarction.

The prevalence of myocardial rupture is rare, many patients could not survive longer, and therefore a careful evaluation becomes difficult and impractical. In the evaluation of myocardial rupture, enzymes such as peak serum creatine phosphokinase (CPK) and cardiac troponins seem to be the most commonly utilized biomarkers $[5,6]$. In addition, cytokines and signal transduction proteins have drawn much attention with regard to assessment of myocardial protection efficacy [7]. Nevertheless, the myocardial damage of postinfarction myocardial rupture has not been sufficiently elucidated. In this article, it is our purpose to summarize and analyze the pertinent laboratory measurements of our patients with postinfarction myocardial rupture after the onset.

\section{METHODS}

\section{Patient Information}

From 2004 to 2008, 19 consecutive patients refering to The Chaim Sheba Medical Center for surgical repair of postinfarction myocardial rupture were enrolled into this retrospective study. A female patient developed myocardial rupture in the Department of Cardiology of our hospital; a male patient had myocardial rupture on the operating table for an elective coronary artery bypass surgery. All other patients were sent to this hospital immediately based on an established diagnosis of myocardial rupture in the local rupture. Multivariant regression analysis did not show any significant relationship between creatine phosphokinase fraction MB (Y) and D-dimer (X1) or fibrinogen (X2).

Conclusion: Myocardial rupture leads to extremely high serum enzyme and coagulation activities except for fibrinogen after the onset. The evaluation of these biomarkers may help in making diagnostic and treatment decisions and in judging the clinical prognosis of such patients.

Descriptors: Blood Coagulation Factors. Cardiac Surgical Procedures. Enzymes. Heart Rupture, Post-Infarction. Myocardial Infarction.

clinics. The interval between the onsets to surgical operation varied from a few minutes to a few hours, usually within 12 hours. Eight $(42.1 \%)$ patients had free wall rupture, $5(26.3 \%)$ had papillary muscle rupture, $5(26.3 \%)$ had ventricular septal rupture, and one $(5.3 \%)$ had double structure (ventricular septum + free wall) rupture. Thirteen patients survived the operation, and six died. Heparin was used during the cardiopulmonary bypass, and cryoprecipitates, platelet concentrates and fresh frozen plasma were used after the surgery, in all patients; while fibrinolytics was unnecessarily used. The intramuscular injection was not practiced.

\section{Diagnostic Criteria of Postinfarction Myocardial Rupture}

1) A recent onset of ECG-/enzyme-evidenced acute myocardial infarction $[8,9]$;

2) A previous history of systemic hypertension [8];

3) A new heart murmur associated with a thrill $[9,10]$;

4) Progressive hemodynamic deterioration (refractory hypotensive condition, pulmonary edema, left heart failure, cardiogenic shock) usually within 6 hours after the onset of acute myocardial infarction, and mechanical ventilation and intra-aortic balloon counterpulsation are often required [8];

5) Echocardiographic or magnetic resonance imaging signs of myocardial rupture and (or) pericardial effusion, or tamponade [11-13]; and,

6) In case of papillary muscle rupture, severe mitral incompetence could be visualized on echocardiography [14].

\section{Observations}

Laboratory findings of serum enzymes and coagulation activities [aspartate aminotransferase (AST), lactate dehydrogenase (LDH), CPK, creatine phosphokinase fraction $\mathrm{MB}$ (CK-MB), international normalized ration (INR), partial thromboplastin time (PTT), D-dimer and fibrinogen], and troponin I were collected and statistically analyzed. Serum AST, LDH, INR and PTT were kinetically presented. Comparisons of the biomarkers and between free wall 
rupture, ventricular septal or papillary muscle rupture, and between the survivors and non-survivors were made. Multivariant regression analysis was applied between CK$\mathrm{MB}$ and D-dimer or fibrinogen.

\section{Statistics}

All the biomarkers mentioned above including serum AST, LDH, CPK, CK-MB, INR, PTT, D-dimer and tropinin I were expressed as means \pm SDs. Unpaired t-tests were used in comparative analyses by using t-test calculator at http://www.graphpad.com/quickcalcs/ttest1.cfm. Twotailed $P$-values $<0.05$ were considered to be statistically significant.

\section{Ethics}

This retrospective study was approved by the Helsinki Committee of The Chaim Sheba Medical Center with an approval number of SMC-7439-09.

\section{RESULTS}

The coagulation and serum enzyme activities increased significantly a few hours after the onset of myocardial rupture except for fibrinogen (Table 1).

Both AST and LDH peaked at day 1 after myocardial rupture, decreased significantly on day 2 , and returned to baseline since day 4 (Figures 1 and 2). INR started to rise on day 3 , reached a peak value on day 6 , and approximated normal value on day 14 (Figure 3 ). PTT peaked on day 2 , and declined gradually since day 3 (Figure 4).

Perioperative troponin I values of eight of these 19 patients were available for evaluation. Two days before the onset of myocardial rupture, the patients troponin was 12.3331 $\mu \mathrm{g} / \mathrm{L}$, from the onset day to the $2^{\text {nd }}$ day after the onset, troponin increased to $0.769-201$ (mean $79 \pm 32.25$, median 4.59) $\mu \mathrm{g} / \mathrm{L}$, 14-20 days after the onset and surgical repair, troponin values decreased to $0.154-1.2 \mu \mathrm{g} / \mathrm{L}$ (Table 2).

Table 1. The coagulation markers and serum enzymes after myocardial rupture.

\begin{tabular}{lccc}
\hline Marker & Mean \pm SD & Range & Normal limit \\
\hline D-dimer $(\mathrm{ng} / \mathrm{ml})$ & $1460.67 \pm 2117.53$ & $184-6535$ & $<20-200$ \\
Fibrinogen (mg/dl) & $329.5 \pm 136.54$ & $179-619$ & $200-400$ \\
Partial thromboplastin time $(\mathrm{sec})$ & $46.5 \pm 46.1$ & $12-130$ & $23-31$ \\
Peak AST (U/L) & $458.33 \pm 992.17$ & $29-4243$ & $7-40$ \\
Peak LDH (U/L) & $1399.06 \pm 1791.12$ & $349-5705$ & $100-260$ \\
Peak CPK (U/L) & $2356.55 \pm 3428.40$ & $52-11255$ & $<10-190$ \\
CK-MB (U/L) & $182.95 \pm 236.47$ & $20.1-810.6$ & $0-25$ \\
CK-MB $(\%)$ & $12.75 \pm 4.15$ & $7.8-22.6$ & $0-6$ \\
Troponin I $(\mu \mathrm{g} / \mathrm{ml})$ & $47.00 \pm 77.83$ & $1.03-201$ & $<0.02-0.07$ \\
\hline
\end{tabular}

$A S T=$ aspartate aminotransferase $; C K-M B=$ creatine phosphokinase fraction $M B ; C P K=C P K=$ creatine phosphokinase; $\mathrm{LDH}=$ lactate dehydrogenase

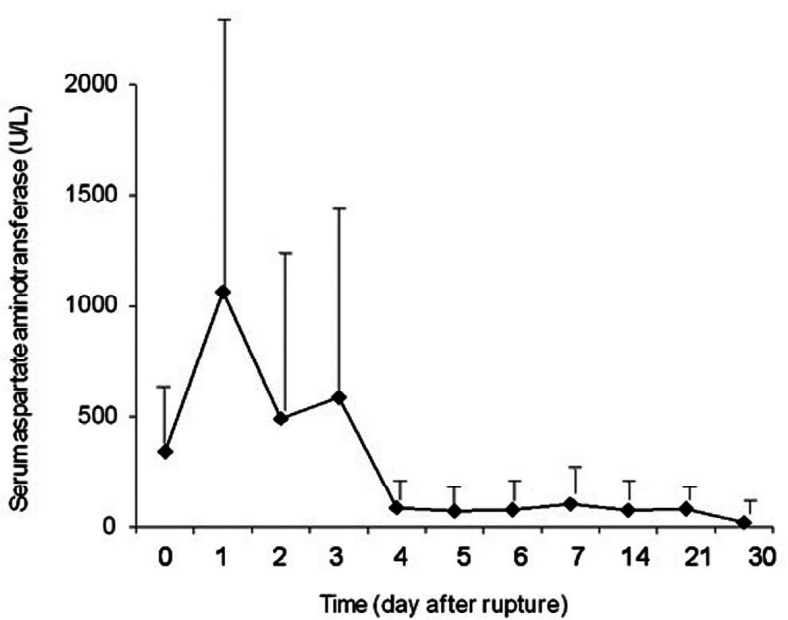

Fig. 1 - Kinetics of serum aspartate aminotransferase after myocardial rupture

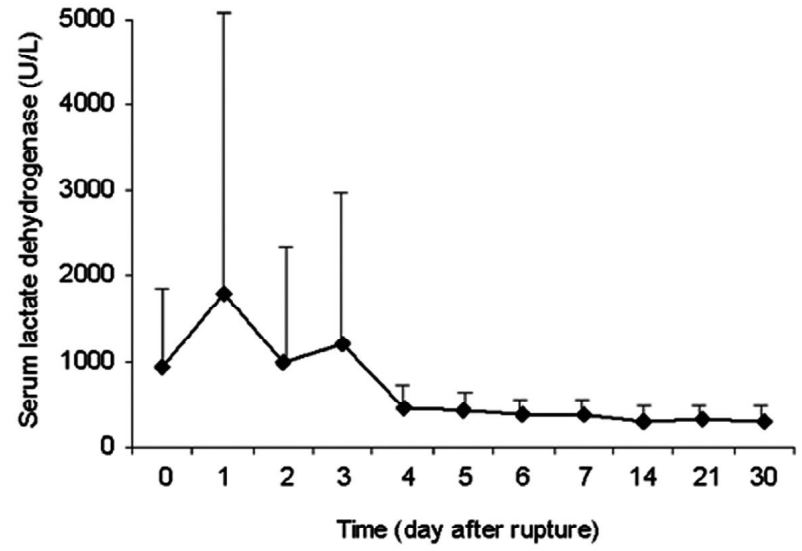

Fig. 2 - Kinetics of serum lactate dehydrogenase after myocardial rupture 


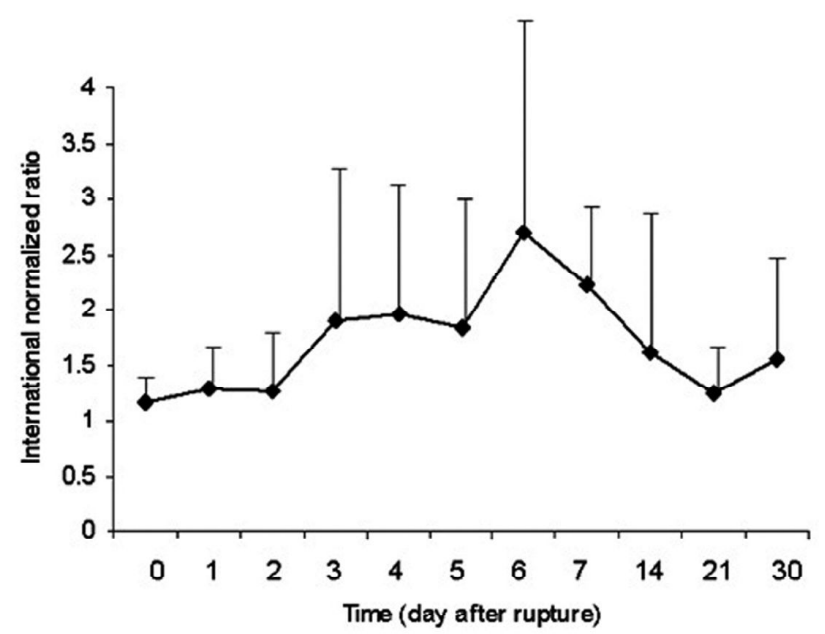

Fig. 3 - Kinetics of international normalized ratio after myocardial rupture

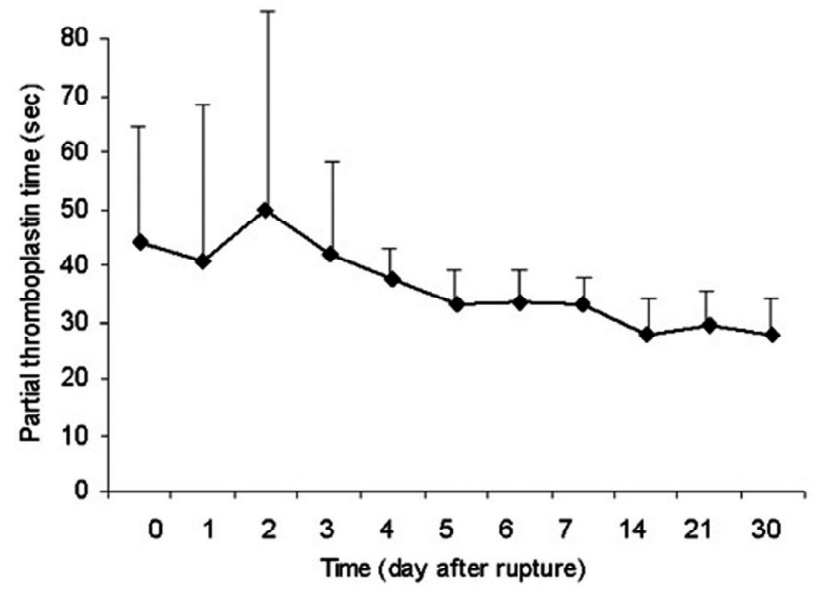

Fig. 4 - Kinetics of partial thromboplastin time after myocardial rupture

Table 2. Troponin values of the patients with myocardial rupture.

\begin{tabular}{lccc}
\hline Patient serial No. & Type of rupture & Day of troponin detection after the onset of & Results $(\mu \mathrm{g} / \mathrm{L})$ \\
\hline 3 & free wall rupture & myocardial infarction & 1.2 \\
9 & free wall rupture & 14 & 53.6 \\
11 & free wall rupture & 2 & 0.154 \\
13 & free wall rupture & 0 & 10.28 \\
14 & free wall rupture & 1 & 3.785 \\
17 & free wall rupture & -2 & 12.3331 \\
10 & papillary muscle rupture & 0 & $0.769 / 1.03$ \\
16 & ventricular septal rupture & 0 & 201 \\
\hline
\end{tabular}

Table 3. A comparison of the the hemostatic markers and creatine kinase fraction MB between free wall rupture and papillary muscle rupture or ventricular septal rupture.

\begin{tabular}{lccc}
\hline Markers & Free wall rupture & $\begin{array}{c}\text { Papillary muscle rupture or ventricular } \\
\text { septal rupture }\end{array}$ & $\mathrm{p}$ value \\
\hline D-dimer (ng/ml) & $1810 \pm 2585.16$ & $514.75 \pm 358.36$ & 0.3576 \\
Fibrinogen (mg/dl) & $278.17 \pm 112$ & $420.80 \pm 131.93$ & 0.0840 \\
Partial thromboplastin time (sec) & $49 \pm 46.35$ & $26.6 \pm 30.43$ & 0.3799 \\
CK-MB (U/L) & $76.26 \pm 41.98$ & $436.07 \pm 329.36$ & 0.0435 \\
\hline
\end{tabular}

$C K-M B=$ creatine phosphokinase fraction $M B$ 
Table 4. A comparison of the the hemostatic markers and serum enzymes between non-survivors and survivors.

\begin{tabular}{lccc}
\hline Markers & Non-survivors & Survivors & p value \\
\hline D-dimer (ng/ml) & $3668 \pm 2968.39$ & $356.40 \pm 373.54$ & 0.0384 \\
Fibrinogen (mg/dl) & $301.40 \pm 117.69$ & $370.83 \pm 163.86$ & 0.4499 \\
Partial thromboplastin time (sec) & $87 \pm 47.73$ & $18 \pm 6.96$ & 0.0261 \\
Peak AST (U/L) & $759.44 \pm 1369.71$ & $157.22 \pm 108.45$ & 0.2071 \\
Peak LDH (U/L) & $2665 \pm 2436.54$ & $593.45 \pm 236.69$ & 0.0116 \\
Peak CPK (U/L) & $5598.75 \pm 4104.10$ & $503.86 \pm 394.50$ & 0.0079 \\
CK-MB (U/L) & $282.08 \pm 314.34$ & $83.55 \pm 28.19$ & 0.0453 \\
\hline
\end{tabular}

$A S T=$ aspartate aminotransferase $; C K-M B=$ creatine phosphokinase fraction $M B ; C P K=$ creatine phosphokinase;

$L D H=$ lactate dehydrogenase

Table 5. Peak serum CPK levels of postinfarction myocardial rupture patients reported previously.

\begin{tabular}{lcc}
\hline Postinfarction myocardial rupture & Peak serum CPK (U/L) & Ref. \\
\hline Free wall rupture & $1168(332-2140)$ & {$[16]$} \\
Free wall rupture (12 hours after onset) & 4262 & {$[17]$} \\
Free wall rupture (blow-out) & 12199 & {$[5]$} \\
Papillary muscle rupture & 1192 & {$[18]$} \\
Ventricular septal rupture & $1100(412-2145)$ & {$[16]$} \\
Double structural rupture & $?(689-3897)$ & {$[19]$} \\
\hline
\end{tabular}

CPK = creatine phosphokinase

The coagulation markers did not show any significant difference between free wall rupture and ventricular septal or papillary muscle rupture, with a PTT value of the latter within the normal limit. In addition, a difference was noted in serum CK-MB between free wall rupture and the other two types of ruptures (Table 3).

Statistical differential significances were found in Ddimer, PTT, peak LDH, peak CPK and CK-MB between nonsurvivors and survivors; while no differences were disclosed in fibrinogen and peak AST between patients with different prognosis (Table 4).

Multivariant regression analysis did not show any significant relationship between CK-MB (Y) and D-dimer $\left(\mathrm{X}_{1}\right)$ or fibrinogen $\left(\mathrm{X}_{2}\right)\left(\mathrm{Y}=-40.967-0.00433 \mathrm{X}_{1}+0.629 \mathrm{X}_{2}\right.$, $R=0.577, R^{2}=0.333$, Adjusted $R^{2}=0.000, P=0.445$ ).

\section{DISCUSSION}

Serum enzymes, including AST, LDH, CPK, CK-MB, and cardiac troponin, etc., have been sufficiently elucidated as cardiac markers indicative of myocardial damage following acute myocardial infarction [15]. However, among these biomarkers, merely peak CPK was commonly reported as an indicator for the evaluation of myocardial rupture secondary to myocardial infarction.
Peak CPK levels were different between postinfarction patients with and without myocardial rupture $(4778 \pm 3575$ vs. $2461 \pm 2661 \mathrm{U} / \mathrm{L}, P=0.005)$. A significant elevation of peak CPK have been found in patients with postinfarction myocardial rupture irrespective of the type of the rupture with a maximal reported value of 12199 U/L (Table 5). We noted an analogous peak CPK value which amounted to $11255 \mathrm{U} / \mathrm{L}$ the second day in a patient with free wall rupture which developed on the operating table for a scheduled coronary artery bypass.

Feneley et al. [16] did not find significance in peak serum CPK between the survivors and non-survivors of patients with postinfarction ventricular septal rupture (1059 \pm 173 U/L vs. $1220 \pm 160 \mathrm{U} / \mathrm{L}, \mathrm{NS})$. But we did on the contrary. Besides, we also observed 3-10 folds differences in D-dimer, peak $\mathrm{LDH}$, and CK-MB between the non-survivors and survivors. Our findings disclosed fibrinogen and peak AST were lack of statistical significance.

The biological aspects of troponins have been clarified in detail. Troponins are mostly located in intact myofibers and only very small amount are free in the cytoplasm [20]. Of the three isoforms troponins $\mathrm{I}, \mathrm{T}$ and $\mathrm{C}$, troponin $\mathrm{C}$ are lack of cardiac specificity [21]. Instead, troponins I and T have shown high specificity and sensitivity for an early diagnosis of coronary artery disease [22], even in patients 
with minor myocardial injury [23]. Troponin I is more sensitive than troponin $\mathrm{T}$ in terms of the prediction of myocardial damage [24-26]. The kinetics of troponins may be mono- or bi-phasic according to a reperfused or a nonreperfused myocardial injury. The typical biphasic pattern may show its first peak in the first few hours after the damage and the second peak may appear in the following days [27]. Therefore, it was recommended that troponin could be detectable 2-4 hours after myocardial damage in blood samples and the elevation in the serum may retain for up to two weeks [22]. Cardiac troponin levels rely on infarct size [28]. When troponin $\mathrm{T}$ value is less than 0.01 , acute myocardial infarction can be ruled out [29]. Nevertheless, implications of troponins were rarely described previously in the patients with postinfarction myocardial rupture. In this regard, Katayama et al. [5] reported an elevated troponin in myocardial infarction patients with no significant differences between myocardial infarction patients with and without myocardial rupture $(0.31$ $\pm 0.55 \mathrm{ng} / \mathrm{ml}$ vs. $0.50 \pm 0.70 \mathrm{ng} / \mathrm{ml}, \mathrm{NS}$ ).

Associations between cardiac death and hemostatic factors were found in early stages. If the coronary flow decrease lasts longer, then the hemostatic mechanisms might be enhanced [30]. D-dimer has been reported to be significantly higher in acute myocardial infarction patients than in controls [31]. D-dimer $>500 \mathrm{ug} / \mathrm{L}$ has an independent diagnostic value for myocardial infarction [32]. However, some authors [33] claimed its poor early sensitivity. Kinetics of D-dimer increase in plasma following ischemic necrosis substantially reflected that of the troponins, and elevated D-dimer lasted much longer than 24 hours [34]. D-dimer was lower in patients with cardiac troponin $\mathrm{T}<0.01 \mathrm{ng} / \mathrm{ml}$ than those with cardiac troponin $\mathrm{T}>0.01 \mathrm{ng} / \mathrm{ml}$. No correlation was found between $\mathrm{D}$-dimer and cardiac troponin $\mathrm{T}$ levels in patients with cardiac troponin $\mathrm{T}>0.01$ $\mathrm{ng} / \mathrm{ml}[1]$.

Fibrinogen functions as an indicator for the evaluation of fibrinogen responses to thrombolytic therapy. A high concentration of fibrinogen was associated with nonpatency infarct related coronary artery [35]. Although it is believed that early postoperative activation of coagulation and fibrinolysis is associated with perioperative myocardial cell damage [36], the findings of our study and of others [37] have led us to believe that fibrinogen has a weak link to the prediction of myocardial damage associated with cardiovascular events.

Schwartz [38] noted that $13 \%$ and $10 \%$ of the 223 patients with suspected acute coronary syndromes had INR and PTT results beyond the reference ranges, and 70\% patients with abnormal coagulation test results had risk factors for coagulation disorder.

Hemodynamic parameters and EuroSCORE appeared to be of prevalent significance in predicting the prognosis, i.e., survival and mortality rate of the patients with myocardial rupture [39]. In this study, we tried to disclose the implications of enzyme and coagulation activities as reliable predictors of patients' prognosis. In patients with myocardial rupture, we observed remarkable elevations of coagulation markers and serum enzymes except fibrinogen. The alterations of INR and PTT suggested that myocardial rupture may be associated with less rapid activation of coagulation factors. Troponin can be elevated to a very high level in the first few days after the onset of postinfarction myocardial rupture. Statistical differential significances in D-dimer, PTT, peak LDH, peak CPK and CK-MB between non-survivors and survivors may indicate the prognostic events in such patient setting. These positive markers were 3-10 folds higher in the nonsurvivors than in the survivors. Although these alterations of the biomarkers could be a result of incorporated processes including myocardial infarction, myocardial rupture, cardiac catheterization, heart operation and cardiopulmonary bypass, etc., myocardial rupture may play the key role in the elevations of the biomarkers.

However, the results of the coagulation tests could be influenced somehow by the use of heparin during the operation and the use of blood components after the surgery. To prevent coagulopathy, the use of blood components, which was based on the coagulation screening tests, would predispose better coagulation results. On the other hand, only a small number of patients were enrolled into this retrospective study due to the fact that postinfarction myocardial rupture had a very low incidence, which constituted a major limitation of the study. Thus, a larger patient population with this disorder is necessary for validating the conclusion.

\section{CONCLUSION}

In conclusion, myocardial rupture leads to an extreme elevation of sensitive markers including serum enzymes and coagulation indicators soon after the onset. The evaluation of these biomarkers may help in making diagnostic and treatment decisions and in judging the clinical prognosis of such patients.

\section{REFERENCES}

1. Moresco RN, Vargas LC, Júnior RH, da Rocha Silla LM. Lack of association between cardiac troponin $\mathrm{T}$ and $\mathrm{D}$-dimer in the evaluation of myocardial damage. J Clin Lab Anal. 2005;19(6):282-4.

2. Cressoni ES, Avanci LE, Braile DM, Lima-Oliveira AP, Taboga SR, Martins AS, et al. Effects of myocardial protection in hypertrophic rabbit hearts: structural and ultra structural analysis. Rev Bras Cir Cardiovasc. 2007;22(1):24-32. 
3. Abreu Filho CAC, Dallan LAO, Lisboa LAF, Platania F, Iglézias JCR, Cabral RH, et al. Surgical treatment of left ventricular free wall rupture after acute myocardial infarction. Rev Bras Cir Cardiovasc. 2002;17(1):6-12.

4. Deja MA, Szostek J, Widenka K, Szafron B, Spyt TJ, Hickey MS, et al. Post infarction ventricular septal defect - can we do better? Eur J Cardiothorac Surg. 2000;18(2):194-201.

5. Katayama T, Nakashima H, Takagi C, Honda Y, Suzuki S, Iwasaki $\mathrm{Y}$, et al. Serum amyloid a protein as a predictor of cardiac rupture in acute myocardial infarction patients following primary coronary angioplasty. Circ J. 2006;70(5):530-5.

6. Barcellos CS, Wender OCB, Azambuja PC. Clinical and hemodynamic outcome following coronary artery bypass surgery in diabetic patients using glucose-insulin-potassium (GIK) solution: a randomized clinical trial. Rev Bras Cir Cardiovasc. 2007;22(3):275-84.

7. Cressoni ES, Avanci LE, Braile DM, Cicogna AC, Lima-Oliveira AP, Gerez MA, et al. Myocardial protection to the hypertrophied heart: the eternal challenge. Rev Bras Cir Cardiovasc. 2008;23(1):97-107.

8. Biörck G, Mogensen L, Nyquist O, Orinius E, Sjögren A. Studies of myocardial rupture with cardiac tamponade in acute myocardial infarction. I. Clinical features. Chest. 1972;61(1):4-6.

9. McQuillan BM, Weyman AE. Severe mitral regurgitation secondary to partial papillary muscle rupture following myocardial infarction. Rev Cardiovasc Med. 2000;1(1):57-60.

10. Sasseen BM, Gigliotti OS, Lavine S, Gilmore PS, Percy R, Bass TA. Hemodynamic complications of ventricular septal rupture after acute myocardial infarction. Catheter Cardiovasc Interv. 2003;60(4):509-14.

11. Stoodley PW, Costa RJ, Richards DA, Thomas L. Acute myocardial infarction complicated by LV free wall rupture: the benefits of echocardiography. Eur J Echocardiogr. 2008;9(1):188-9.

12. Ekim H, Tuncer M, Basel H. Repair of ventricle free wall rupture after acute myocardial infarction: a case report. Cases J. 2009;2:9099.

13. Shiozaki AA, Filho RA, Dallan LA, de Oliveira SA, Nicolau JC, Rochitte CE. Left ventricular free-wall rupture after acute myocardial infarction imaged by cardiovascular magnetic resonance. J Cardiovasc Magn Reson. 2007;9(4):719-21.

14. Kranidis A, Koulouris S, Filippatos G, Sideris A, Anthopoulos L. Mitral regurgitation from papillary muscle rupture: role of transesophageal echocardiography. J Heart Valve Dis. 1993;2(5):529-32.

15. Karras DJ, Kane DL. Serum markers in the emergency department diagnosis of acute myocardial infarction. Emerg Med Clin North Am. 2001;19(2):321-37.

16. Feneley MP, Chang VP, O'Rourke MF. Myocardial rupture after acute myocardial infarction. Ten year review. Br Heart J. 1983;49(6):550-6.

17. Kwong R, Carere RG, Thompson CR, Lichtenstein S. Ventricular rupture during coronary angioplasty for acute reinfarction. Cathet Cardiovasc Diagn. 1998;43(2):190-4.

18. Inoue T, Iemura J, Saga T. Successful surgical treatment of mitral regurgitation for complete rupture of the anterior papillary muscle after acute myocardial infarction. Jpn J Thorac Cardiovasc Surg. 2003;51(10):565-8.

19. Tanaka K, Sato N, Yasutake M, Takeda S, Takano T, Ochi M, et al. Clinicopathological characteristics of 10 patients with rupture of both ventricular free wall and septum (double rupture) after acute myocardial infarction. J Nippon Med Sch. 2003;70(1):21-7.

20. Eisenman A. Troponin assays for the diagnosis of myocardial infarction and acute coronary syndrome: where do we stand? Expert Rev Cardiovasc Ther. 2006;4(4):509-14.

21. Babuin L, Jaffe AS. Troponin: the biomarker of choice for the detection of cardiac injury. CMAJ. 2005;173(10):1191-202.

22. Daubert MA, Jeremias A. The utility of troponin measurement to detect myocardial infarction: review of the current findings. Vasc Health Risk Manag. 2010;6:691-9.

23. Gerhardt W, Ljungdahl L. Detection of myocardial damage by serial measurements of cardiac troponin T, CK MBmass, and TROPT rapid test. Cardiovasc Drugs Ther. 1997;11(Suppl 1):227-40.

24. Roppolo LP, Fitzgerald R, Dillow J, Ziegler T, Rice M, Maisel A. A comparison of troponin $\mathrm{T}$ and troponin I as predictors of cardiac events in patients undergoing chronic dialysis at a Veteran's Hospital: a pilot study. J Am Coll Cardiol. 1999;34(2):448-54.

25. Oliveira MA, Botelho PH, Brandi AC, Santos CA, Soares MJ, Zaiantchick M, et al. The importance of troponin I in the diagnosis of myocardial infarction in the postoperative of coronary artery bypass graft surgery. Rev Bras Cir Cardiovasc. 2009;24(1):11-4.

26. Ferreira CA, Vicente WV, Evora PR, Rodrigues AJ, Klamt JG, Carlotti AP, et al. High-dose aprotinin does not affect troponin I, N-Terminal pro-B-type natriuretic peptid and renal function in children submitted to surgical correction with extracorporeal circulation. Rev Bras Cir Cardiovasc. 2009;24(4):519-32.

27. Nigam PK. Biochemical markers of myocardial injury. Indian J Clin Biochem. 2007;22(1):10-7. 
28. Antman EM, Tanasijevic MJ, Thompson B, Schactman M, McCabe $\mathrm{CH}$, Cannon $\mathrm{CP}$, et al. Cardiac-specific troponin I levels to predict the risk of mortality in patients with acute coronary syndromes. N Engl J Med. 1996;335(18):1342-9.

29. Chan $\mathrm{D}, \mathrm{Ng}$ LL. Biomarkers in acute myocardial infarction. BMC Med. 2010;8:34.

30. Kostis JB, Baughman DJ, Kuo PT. Association of recurrent myocardial infarction with hemostatic factors: a prospective study. Chest 1982;81(5):571-5.

31. Tanaka M, Suzuki A. Hemostatic abnormalities in acute myocardial infarction as detected by specific blood markers. Thromb Res. 1994;76(3):289-98.

32. Bayes-Genis A, Mateo J, Santaló M, Oliver A, Guindo J, Badimon L, et al. D-Dimer is an early diagnostic marker of coronary ischemia in patients with chest pain. Am Heart $\mathbf{J}$ 2000;140(3):379-84.

33. Mair J, Genser N, Maier J, Lechleitner P, Dienstl F, Puschendorf B. Markers of activated coagulation for early diagnosis of acute myocardial infarction. Clin Chim Acta. 1997;267(2):239-45

34. Lippi G, Filippozzi L, Montagnana M, Salvagno GL, Guidi GC. Diagnostic value of D-dimer measurement in patients referred to the emergency department with suspected myocardial ischemia. J Thromb Thrombolysis. 2008;25(3):247-50.

35. Ranjadayalan K, Stevenson R, Marchant B, Umachandran V, Davies SW, Syndercombe-Court D, et al. Streptokinase induced defibrination assessed by thrombin time: effects on residual coronary stenosis and left ventricular ejection fraction. Br Heart J. 1992;68(2):171-5.

36. Böttiger BW, Snyder-Ramos SA, Lapp W, Motsch J, Aulmann M, Schweizer M, et al; Ischemia Research and Education Foundation. Association between early postoperative coagulation activation and peri-operative myocardial ischaemia in patients undergoing vascular surgery. Anaesthesia. 2005;60(12):1162-7.

37. Shlipak MG, Ix JH, Bibbins-Domingo K, Lin F, Whooley MA. Biomarkers to predict recurrent cardiovascular disease: the Heart and Soul Study. Am J Med 2008;121(1):50-7.

38. Schwartz D. Utility of routine coagulation studies in emergency department patients with suspected acute coronary syndromes. Isr Med Assoc J 2005;7(8):502-6.

39. Sá MP, Sá MV, Barbosa CH, Silva NP, Escobar RR, Rueda RG, et al. Clinical and surgical profile of patients operated for postinfarction interventricular septal rupture. Rev Bras Cir Cardiovasc. 2010;25(3):341-9. 